\title{
ANALISIS PENGARUH INFLASI, HARGA EMAS, KURS RUPIAH TERHADAP SUKU BUNGA BULANAN BI SEBELUM DAN SAAT PANDEMI COVID 19
}

\author{
Miftahul Janah \\ Sekolah Tinggi Ilmu Ekonomi Pancasetia Banjarmasin \\ Jl. Ahmad Yani Km. 5.5 Banjarmasin \\ arrahmanbanjarbaru@gmail.com
}

\begin{abstract}
Abstrak: Suku Bunga (interest) ialah harga/biaya atau balas-jasa yang harus dibayar untuk penggunaan sejumlah uang selama jangka waktu tertentu oleh pihak yang meminjam kepada pihak yang meminjamkan. Suku bunga (rate of interest) biasanya dinyatakan sebagai \% (presentase) per tahun dari pokok pinjaman". Tujuan dari penelitian ini adalah untuk mengetahui pengaruh Inflasi, Harga Emas, dan kurs Rupiah terhadap suku bunga sebelum dan saat pandemic covid 19. Sampel penelitian ini adalah data inflasi, harga emas, kurs rupiah dan Suku bunga Bank Indonesia dari mulai Januari 2019 samai dengan 31 Desember 2019 dan awal bulan Januari 2020 sampai dengan 31 Desember 2020. Variabel bebas adalah Inflasi, Harga Emas, dan kurs Rupiah sedangkan variabel terikat adalah Suku Bunga. Analisis data yang digunakan terdiri dari analisis korelasi, analisis determinasi, uji t, uji $\mathrm{F}$, dan analisis regresi linier berganda. Hasil penelitian ini menunjukkan bahwa Inflasi, Harga emas dan Kurs rupiah secara simultan berpengaruh signifikan terhadap Suku bunga bulanan Bank Indonesia sebelum dan saat pandemi Covid-19, Inflasi, Harga emas dan Kurs rupiah secara parsial berpengaruh signifikan terhadap Suku bunga bulanan Bank Indonesia sebelum pandemi Covid-19. Dan Harga emas secara parsial tidak berpengaruh signifikan terhadap Suku bunga bulanan Bank Indonesia saat pandemi Covid-19, inflasi adalah faktor yang mempunyai pengaruh dominan terhadap Suku bunga bulanan Bank Indonesia sebelum dan saat pandemi Covid-19.
\end{abstract}

Kata Kunci : Inflasi, Harga Emas, Kurs Rupiah, Suku Bunga 


\section{Latar Belakang}

Penelitian ini untuk mengetahui serta membuktikan hubungan tingkat inflasi, harga emas maupun kurs rupiah yang terjadi pada kondisi normal akan berbeda dengan keadaan masa pandemi covid-19 terhadap suku bunga bulanan Bank Indonesia baik secara bersama-sama maupun masing-masing variabel terhadap suku bulanan Bank Indonesia, termasuk didalamnya variabel dominan yang mempengaruhi suku bunga bulanan Bank Indonesia.

\section{Studi Literatur}

Suku Bunga (interest) ialah harga/biaya atau balas-jasa yang harus dibayar untuk penggunaan sejumlah uang selama jangka waktu tertentu oleh pihak yang meminjam kepada pihak yang meminjamkan. Suku bunga (rate of interest) biasanya dinyatakan sebagai \% (prosentase) per tahun dari pokok pinjaman”.

Inflasi yaitu meningkatnya hargaharga secara umum dan terus menerus. Kenaikan dari satu atau dua barang saja tidak dapat disebut inflasi kecuali bila kenaikan itu meluas (atau mengakibatkan kenaikan harga) pada barang lainnya. Kebalikan dari inflasi disebut deflasi.

Emas merupakan salah satu pilihan investasi, dimana risikonya cenderung lebih rendah dibanding dengan investasi lainnya. Hal tersebut dikarenakan harga emas yang jarang mengalami penurunan, sehingga seringkali investasi emas diharapkan akan memperoleh imbal hasil yang tinggi dengan tingkat risiko tertentu.

Kurs merupakan salah satu harga yang terpenting dalam perekonomian terbuka mengingat pengaruh yang demikian besar bagi neraca transaksi berjalan maupun variable-variabel makro ekonomi yang lainnya.

\section{Penelitian Terdahulu}

Henry Wijaya, 2016. Pengaruh Inflasi dan Product Domestik Bruto terhadap Suku Bunga Riil dengan menggunakan Pendekatan Taylor Rule. STIE Rahmaniyah, Sekayu. Penelitian ini bertujuan untuk mengetahu pengaruh inflasi dan PDB terhadap suku bunga riil. tingkat suku bunga, data penelitian pada periode 2013 hingga 2015. Teknik analisis data berupa analisis deskriptif, uji asumsi klasik (uji normalitas, uji autokorelasi, uji multikoloniaritas, uji heteroskedasitas), serta uji hipotesis yaitu uji $t$ (parsial), uji $F$ (uji simultan) dan uji koefisien determinasi..

Hasil penelitian ini menunjukkan bahwa Inflasi dan PDB memiliki pengaruh negatip terhadap suku bunga riil, artinya setiap kenaikan nominal pada vriabel bebas akan menyebabkan tingkat suku bunga riil turun. Persamaan penelitian terdahulu dengan penelitian ini yaitu meneliti variable inflasi terhadap suku bunga bank yang berlaku di Indonesia, sedangkan perbedaannya terletak pada variabel bebasnya, dalam penelitian terdahulu menggunakan product domestic bruto, sedangkan dalam penelitian ini menggunakan harga emas, kurs rupiah.

\section{Metode Penelitian}

Bank Indonesia merupakan Bank Sentral di Indonesia yang independen dalam melaksanakan tugas dan wewenangnya yang dimulai ketika diterbitkan Undang-Undang No. 23 tahun 1999 tentang Bank Indonesia yang dinyatakan berlaku pada tgl. 17 Mei 1999 dan sebagaimana telah diubah dengan Undang-Undang No.6 tahun 2009. Populasi dalam penelitian ini adalah data inflasi, harga emas, kurs rupiah dan Suku bunga bulanan Bank Indonesia mulai Januari 2019 sampai 31 Desember 2019 dan awal bulan Januari 2020 sampai dengan 31 Desember 2020, masing-masing variabel sebanyak 24 data (time series). Teknik Sampling yang digunakan dalam penelitian adalah Non Probability Sampling. Variabel yang 
digunakan dalam penelitian ini adalah variable bebas dan variable terikat dengan menggunakan uji asumsi klasik.

\section{Hasil Penelitian Sebelum Pandemi Covid 19}

\section{Analisis Uji Asumsi Klasik}

\section{Uji Multikolinieritas}

Tabel 5.3

Hasil Uji Multikolinieritas

\begin{tabular}{|l|c|c|c|}
\hline \multicolumn{1}{|c|}{ Variabel } & Tolerance & VIF & Kesimpulan \\
\hline Inflasi (X1) & 0.957 & 1,045 & Nonmultikolinieritas \\
\hline $\begin{array}{l}\text { Harga Emas } \\
\text { (X2) }\end{array}$ & 0.934 & 1,071 & Nonmultikolinieritas \\
\hline $\begin{array}{l}\text { Kurs Rupiah } \\
\text { (X3) }\end{array}$ & 0.942 & 1,062 & Nonmultikolinieritas \\
\hline
\end{tabular}

Sumber : Data diolah

Berdasarkan Tabel 5.3 menunjukkan bahwa hasil perhitungan nilai tolerance lebih dari 0,10 atau $10 \%$ dan nilai variance inflation factor (VIF) kurang dari 10. Jadi dapat disimpulkan bahwa model regresi yang digunakan dalam penelitian ini tidak terjadi gejala multikolonieritas antar variabel bebasnya.

\section{Uji Heteroskedastisitas}

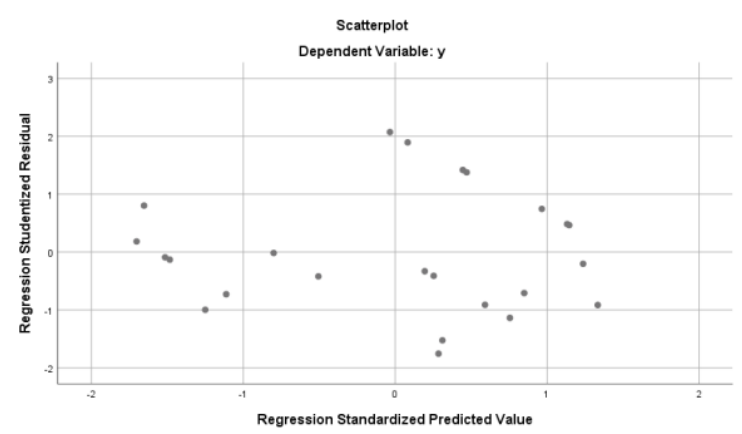

Gambar 5.1 Diagram Scatterplot

Sumber : Data diolah

Berdasarkan grafik scatterplots di atas ini terlihat titik-titik menyebar secara acak serta tersebar baik di atas maupun di bawah angka 0 pada sumbu Y. Hal ini dapat disimpulkan bahwa tidak terjadi gejala heteroskedastisitas pada model regresi, sehingga model regresi layak dipakai untuk memprediksi Suku Bunga Bulanan Bank Indonesia.

\section{Uji Normalitas}

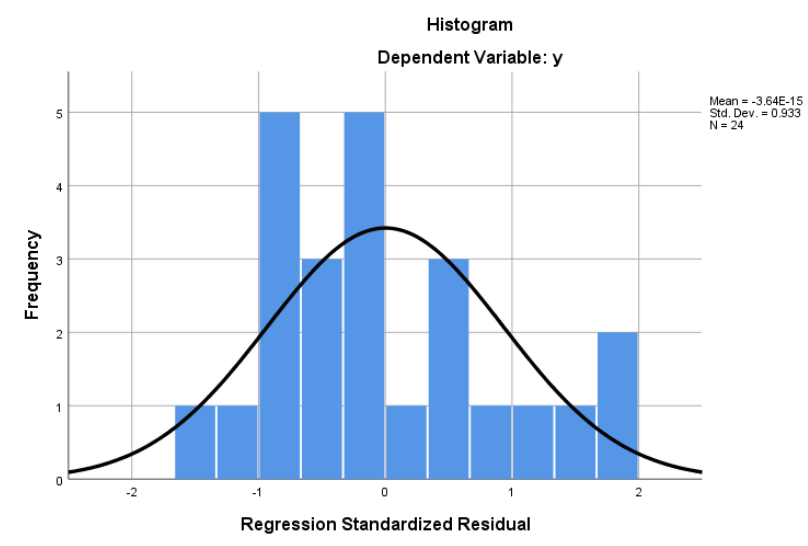

Gambar 5.3 Histogram Normalitas Sumber : Data diolah

Berdasarkan tampilan grafik histogram maupun grafik normal plot dapat disimpulkan bahwa grafik histogram memberikan pola distribusi yang mendekati normal. Sedangkan pada grafik normal plot terlihat titik-titik menyebar disekitar garis diagonal, serta penyebarannya mengikuti arah garis diagonal. Kedua grafik ini menunjukkan bahwa model regresi layak dipakai karena memenuhi asumsi normalitas.

\section{Uji Autokorelasi}

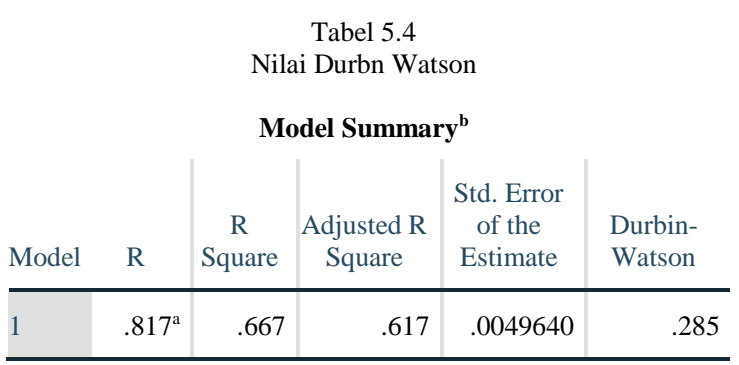

a. Predictors: (Constant), x3, x1, x2

b. Dependent Variable: y

Uji autokorelasi merupakan uji untuk mendeteksi terdapat atau tidaknya autokorelasi pada penelitian ini. Deteksi terjadi autokorelasi apabila data penelitian 
dalam bentuk time series, maka gejala autokorelasi dapat dideteksi dengan indikasi nilai koefisien Durbin Watson sebesar diantara -2 dan +2 . Dalam tabel tersebut diatas nilai Durbin Watson sebesar 0,285 menunjukkan masih lebih besar dari -2 dan masih lebih kecil dari +2 , berarti dalam penelitian ini tidak terjadi autokorelasi dan penelitian ini layak untuk dilakukan.

\section{Hasil Uji Regresi Linier Berganda Sebelum Pandemi Covid-19}

Analisis regresi ini digunakan untuk menghitung besarnya pengaruh antara variabel bebas, yaitu Inflasi (X1), Harga emas (X2) dan Kurs Rupiah (X3) terhadap variabel terikat yaitu Suku Bunga Bulanan Bank Indonesia (Y) sebelum Covid-19 Persamaan regresi digunakan untuk mengetahui bentuk hubungan antara variabel bebas dengan variabel terikat. Dengan menggunakan bantuan SPSS for Windowsver 21.0 di dapat model regresi seperti pada Tabel 5.5 berikut.

Tabel 5.5

Koefisien Regresi Linier Berganda

\begin{tabular}{|c|c|c|c|c|c|c|}
\hline \multicolumn{7}{|c|}{ Coefficients $^{\mathrm{a}}$} \\
\hline \multirow{2}{*}{\multicolumn{2}{|c|}{ Model }} & \multicolumn{2}{|c|}{$\begin{array}{l}\text { Unstandardized } \\
\text { Coefficients }\end{array}$} & \multirow{2}{*}{$\begin{array}{c}\text { Standardized } \\
\text { Coefficients } \\
\text { Beta }\end{array}$} & \multirow[b]{2}{*}{$\mathrm{t}$} & \multirow[b]{2}{*}{ Sig. } \\
\hline & & B & $\begin{array}{l}\text { Std. } \\
\text { Error }\end{array}$ & & & \\
\hline \multirow[t]{4}{*}{1} & (Constant) & .061 & .013 & & 4.528 & .002 \\
\hline & x1_2019 &, 124 & .445 & ,237 & 2,279 & .018 \\
\hline & x2_2019 & .029 & .048 & .103 & 3.592 & .042 \\
\hline & x3_2019 & .068 & .129 & .200 & 2.528 & .006 \\
\hline
\end{tabular}

Berdasarkan pada Tabel 5.5 didapatkan persamaan regresi sebagai berikut:

$\mathrm{Y}=0,061+0,124 \mathrm{X} 1+0,029 \mathrm{X} 2-+0,068$ $\mathrm{X} 3+\mathrm{e}$
Dari persamaan di atas dapat diinterpretasikan sebagai berikut:

1. Nilai konstanta (a) bernilai sebesar 0,061. Nilai tersebut menyatakan bahwa variabel independen (Inflasi, Harga Emas dan Kurs Rupiah) jika dianggap konstan maka Suku Bunga Bulanan Bank Indonesia sebelum Covid-19 adalah sebesar 0,061

2. Suku Bunga Bulanan Bank (Y) sebelum Covid-19 akan meningkat apabila ada penambahan satu satuan Inflasi (X1). Artinya apabila terjadi peningkatan inflasi maka Suku Bunga Bulanan Bank Indonesia sebelum Covid-19 akan meningkat sebesar 0,124 satuan dengan asumsi variabel yang lainnya dianggap konstan.

3. Suku Bunga Bulanan Bank (Y) sebelum Covid-19 akan meningkat untuk setiap tambahan Harga emas (X2). Artinya apabila harga emas mengalami peningkatan atau penurunan, maka Suku Bunga Bulanan Bank Indonesia (Y) sebelum Covid-19 akan meningkat atau menurun sebesar 0,029 satuan dengan asumsi variabel yang lainnya dianggap konstan.

4. Suku Bunga Bulanan Bank Indonesia (Y) sebelum Covid-19 akan meningkat untuk setiap tambahan Kurs Rupiah (X3). Artinya apabila Kurs Rupiah mengalami peningkatan, maka Suku Bunga Bulanan Bank Indonesia (Y) sebelum Covid-19 akan meningkat atau menurun sebesar 0,068 satuan dengan asumsi variabel yang lainnya dianggap konstan. Berdasarkan interpretasi di atas, dapat diketahui besarnya kontribusi variabel bebas terhadap variabel terikat, antara lain Inflasi sebesar 0,124, Harga Emas sebesar 0,029 dan Kurs Rupiah sebesar 0,068. Sehingga dapat disimpulkan bahwa Inflasi, Harga Emas dan Kurs Rupiah berpengaruh positif terhadap Suku Bunga Bulanan Bank Indonesia. Dengan kata lain, apabila terjadi perubahan atas variabel Inflasi, Harga 
Emas dan Kurs Rupiah meningkat, maka akan diikuti peningkatan Suku Bulanan Bunga Bulanan Bank Indonesia sebelum covid-19.

\section{Koefisen Determinasi}

Uji ini bertujuan untuk menentukan proporsi atau presentase total variasi dalam variabel terikat yang dapat dijelaskan variabel bebas secara bersama-sama.

Tabel 5.6

Koefisien Determinasi

\begin{tabular}{ll|l|l|l|l}
\multicolumn{9}{c}{} & \multicolumn{9}{c}{ Model Summary } \\
Model & $\mathrm{R}$ & $\begin{array}{c}\mathrm{R} \\
\text { Square }\end{array}$ & $\begin{array}{c}\text { Adjusted R } \\
\text { Square }\end{array}$ & $\begin{array}{c}\text { Std. Error } \\
\text { of the } \\
\text { Estimate }\end{array}$ & $\begin{array}{c}\text { Durbin- } \\
\text { Watson }\end{array}$ \\
\hline 1 & $.756^{\mathrm{a}}$ & .571 & .602 & .0046843 & .301 \\
\hline
\end{tabular}

a. Predictors: (Constant), x3_2019, x1_2019, x2_2

b. Dependent Variable: y_2019

Dari analisis pada Tabel 5.6 diperoleh hasil Adjusted $R$ Square sebesar 0,602. artinya bahwa 60,20\% variabel Suku Bunga Bulanan (Y) Bank Indonesia sebelum covi-19 dapat dijelaskan oleh variabel bebasnya, yaitu Inflasi (X1), Harga Emas (X2) dan Kurs Rupiah (X3) sebesar $60,20 \%$, sedangkan sisanya $39,80 \%$ variabel Suku Bunga Bulanan Bank Indonesia (Y) sebelum covid-19 dijelaskan oleh variabel-variabel lain yang tidak diteliti dalam penelitian ini.

\section{Hasil Uji Hipotesis}

Pengujian hipotesis merupakan bagian penting dalam penelitian, setelah data terkumpul dan diolah. Kegunaan utamanya adalah untuk membuktikan hipotesis yang disusun oleh peneliti.

\section{Hipotesis 1 (F test / Simultan)}

Pengujian $\mathrm{F}$ atau pengujian model simultan digunakan untuk mengetahui apakah hasil dari analisis regresi linier berganda secara simultan berpengaruh signifikan atau tidak, dengan kata lain model yang diduga tepat/sesuai atau tidak. Jika hasilnya signfikan, maka Ho ditolak dan Ha diterima. Sedangkan jika hasilnya tidak signifikan, maka Ho diterima dan Ha ditolak. Hal ini dapat juga diformulasikan sebagai berikut : Ho ditolak jika $\mathrm{F}$ hitung $>\mathrm{F}$ tabel dan Ho diterima jika $F$ hitung $<F$ tabel. Hasil uji $\mathrm{F}$ dapat dilihat pada tabel 5.7 berikut :

Tabel 5.7

Koefisien Uji F (Uji Simultan)

\begin{tabular}{|c|c|c|c|c|c|}
\hline \multirow[b]{2}{*}{ Model } & \multicolumn{3}{|c|}{ ANOVA $^{a}$} & \multirow[b]{2}{*}{$\mathrm{F}$} & \multirow[b]{2}{*}{ Sig. } \\
\hline & $\begin{array}{l}\text { Sum of } \\
\text { Squares }\end{array}$ & $\mathrm{df}$ & $\begin{array}{l}\text { Mean } \\
\text { Square }\end{array}$ & & \\
\hline 1 Regression & .000 & 3 & .000 & 15,565 & $.0463^{\mathrm{b}}$ \\
\hline Residual & .000 & 8 & .000 & & \\
\hline Total & .000 & 11 & & & \\
\hline
\end{tabular}

a. Dependent Variable: y_2019

b. Predictors: (Constant), x3_2019, x1_2019, x2_2019

Berdasarkan Tabel 5.7 nilai $\mathrm{F}$ hitung sebesar 15,565. sedangkan $\mathrm{F}$ tabel $(\alpha=$ 0.05. $\mathrm{df}=\mathrm{n}-\mathrm{k}-1=12-3-1=8)$ adalah sebesar 4,070 Karena $\mathrm{F}$ hitung > F tabel yaitu $15,565>4,070$ atau nilai sig $\mathrm{F}(0,0463)<\alpha$ $=0.05$ maka model analisis regresi adalah signifikan. Hal ini berarti Ho ditolak dan $\mathrm{Ha}$ diterima, sehingga dapat disimpulkan bahwa variabel bebas Inflasi (X1), Harga Emas (X2) dan Kurs Rupiah (X3) secara simultan berpengaruh signifikan terhadap Suku Bunga Bulanan Bank Indonesia (Y) sebelum covid-19

2. Hipotesis 2 ( $\mathrm{t}$ test / Parsial)

Uji $t$ test digunakan untuk mengetahui apakah masing-masing variabel bebas secara parsial mempunyai pengaruh yang signifikan terhadap variabel terikat. Dapat juga dikatakan jika t hitung > 
$\mathrm{t}$ tabel atau -t hitung < - $\mathrm{t}$ tabel maka hasilnya signifikan dan berarti $\mathrm{HO}$ ditolak dan Ha diterima. Sedangkan jika t hitung < $\mathrm{t}$ tabel atau -t hitung > -t tabel maka hasilnya tidak signifikan dan berarti Ho diteima dan Ha ditolak. Berdasarkan Tabel 5.8 diperoleh rangkuman hasil koefisien regresi linier berganda sebagai berikut :

Tabel 5.8

Hasil uji t (Uji Parsial)

\begin{tabular}{|c|c|c|c|c|c|c|}
\hline & & & oefficier & & & \\
\hline & & $\begin{array}{r}\text { Unstand } \\
\text { Coeffi }\end{array}$ & $\begin{array}{l}\text { ardized } \\
\text { ients }\end{array}$ & $\begin{array}{l}\text { Standardized } \\
\text { Coefficients }\end{array}$ & & \\
\hline & & B & $\begin{array}{l}\text { Std. } \\
\text { Error }\end{array}$ & Beta & $\mathrm{t}$ & Sig. \\
\hline 1 & (Constant) & .061 & .013 & & 4.528 & .002 \\
\hline & x1_2019 & ,124 & .445 & ,237 & 2,279 & .018 \\
\hline & x2_2019 & .029 & .048 & .103 & 3.592 & .042 \\
\hline & x3_2019 & .068 & .129 & .200 & 2.528 & .006 \\
\hline
\end{tabular}

Berdasarkan tabel 5.8 di atas dapat dijelaskan sebagai berikut:

a. Hasil $t$ test antara Inflasi (X1) dengan Suku Bunga Bulanan Bank Indonesia (Y) sebelum covid-19 menunjukkan $\mathrm{t}$ hitung $=2,279$, sedangkan $\mathrm{t}$ tabel $(\alpha=$ $0.05 ; \mathrm{df}=\mathrm{n}-\mathrm{k}-1=12-3-1=8)$ adalah sebesar 1,860. Karena t hitung $>t$ tabel yaitu $2,279>$ atau nilai sig $\mathrm{t}(0,018)<$ $\alpha=0.05$ maka pengaruh Inflasi (X1) terhadap Suku Bunga Bulanan Bank Indonesia (Y) sebelum pandemic covid19 adalah signifikan. Hal ini berarti Ho ditolak dan Ha diterima, sehingga dapat disimpulkan bahwa Suku Bunga Bulanan Bank Indonesia (Y) sebelum pandemic covid-19 dapat dipengaruhi secara signifikan oleh Inflasi atau dengan kata lain bahwa perubahan tingkat Inflasi maka Suku Bunga Bulanan Bank Indonesi (Y) sebelum pandemic covid-19 akan mengalami perubahan peningkatan secara signfikan. b. Hasil t test antara Harga Emas (X2) dengan Suku Bunga Bulanan Bank Indonesia (Y) sebelum pandemic covid19 menunjukkan $\mathrm{t}$ hitung $=3,592$ sedangkan $\mathrm{t}$ tabel $(\alpha=0.05 ; \mathrm{df}=\mathrm{n}-\mathrm{k}-$ $1=12-3-1=8)$ adalah sebesar 1,860 Karena $\mathrm{t}$ hitung $>\mathrm{t}$ tabel yaitu 3,592 $>$ 1,860 atau nilai sig $\mathrm{t}(0,042)<\alpha=0.05$ maka pengaruh Harga Emas (X2) terhadap Suku Bunga Bulanan Bank Indonesia (Y) sebelum covid-19 adalah signifikan. Hal ini berarti Ho ditolak dan Ha diterima, sehingga dapat disimpulkan bahwa Suku Bunga Bulanan Bank Indonesia (Y) sebelum covid-19 dapat dipengaruhi secara signifikan oleh Harga Emas atau dengan naik dan turunnya harga emas dengan kondisi yang berubah secara konsisten maka Suku Bunga Bulanan Bank Indonesia (Y) sebelum covid-19 akan mengalami peningkatan.

c. Hasil t test antara Kurs Rupiah (X3) dengan Suku Bunga Bulanan Bank Indonesia (Y) sebelum covid-19 menunjukkan $\mathrm{t}$ hitung $=2,528$ Sedangkan $\mathrm{t}$ tabel $(\alpha=0.05 ; \mathrm{df}=\mathrm{n}-\mathrm{k}$ $1=12-3-1=8)$ adalah sebesar 1,860. Karena t hitung $>\mathrm{t}$ tabel yaitu 2,528 $>$ 1,860 atau nilai sig $\mathrm{t}(0,006)<\alpha=0.05$ maka pengaruh Kurs Rupiah (X3) terhadap Suku Bunga Bulanan Bank Indonesia (Y) sebelum covid-19 adalah signifikan. Hal ini berarti Ho ditolak dan Ha diterima, sehingga dapat disimpulkan bahwa Suku Bunga Bulanan Bank Indonesia (Y) sebelum covid-19 dapat dipengaruhi secara signifikan oleh Kurs Rupiah (X3) atau dengan semakin melemah Kurs Rupiah maka Suku Bunga Bulanan Bank Indonesia (Y) sebelum covid-19 akan mengalami peningkatan secara signifikan.

Berdasarkan hasil temuan penelitian tersebut dapat disimpulkan bahwa variabel bebas mempunyai pengaruh signifikan terhadap Suku Bunga Bulanan 
Bank Indonesia (Y) sebelum covid-19 secara simultan dan parsial.

\section{Hipotesis 3 (Uji Dominan)}

Diantara ketiga variabel bebasnya, bahwa variabel bebas yang berpengaruh dominan terhadap Suku Bunga Bulanan Bank Indonesia (Y) sebelum covid-19 adalah Inflasi karena memiliki nilai koefisien beta 0,237 paling besar dibandingkan dengan variabel yang lain.

Hal ini berarti Ho ditolak dan $\mathrm{Ha}$ diterima, sehingga dapat disimpulkan bahwa Inflasi merupakan variabel dominan yang mempengaruhi Suku Bunga Bulanan Bank Indonesia (Y) sebelum covid-19

\section{Pembahasan Sebelum Pandemi Covid- 19}

Berdasarkan temuan penelitian yang telah dilakukan dapat diketahui secara umum bahwa variabel Inflasi (X1), variabel Harga Emas (X2), dan variabel Kurs Rupiah (X3) berpengaruh terhadap Suku Bunga Bulanan Bank Indonesia (Y) sebelum covid-19 hasilnya dapat dinyatakan baik.

1. Variabel Inflasi (X1), variabel Harga Emas (X2), dan variabel Kurs Rupiah (X3) secara simultan berpengruh signifikan terhadap Suku Bunga Bulanan Bank Indonesia (Y) sebelum covid-19

Hasil temuan penelitian membuktikan bahwa secara simultan terdapat pengaruh yang signifikan dari variabel bebas yaitu variabel Inflasi, Harga Emas, dan Kurs Rupaih terhadap Suku Bunga Bulanan Bank Indonesia (Y) sebelum covid-19, hal tersebut dibuktikan dengan nilai $\mathrm{F}$ hitung $>$ dari $\mathrm{F}$ tabel. Apabila ketiga variabel bebas tersebut mengalami perubahan maka Suku Bunga Bulanan Bank Indonesia (Y) sebelum covid-19 ikut meningkat dan begitu pula sebaliknya apabila dalam implementasinya semakin tidak konsisten dan semakin melemah maka Suku Bunga Bulanan Bank Indonesia (Y) sebelum covid-19 akan juga semakin meningkat.

Ketiga variabel tersebut mempunyai peran penting dalam perubahan Suku Bunga Bulanan Bank Indonesia (Y) sebelum covid-19, karena ketiga variabel tersebut menjadi pertimbangan dalam menentukan Suku Bunga Bulanan Bank Indonesia (Y) sebelum covid-19,

2 Inflasi (X1), Harga Emas (X2) dan Kurs Rupiah (X3) secara parsial berpengruh signifikan terhadap Suku Bunga Bulanan Bank Indonesia (Y) sebelum covid-19,

Temuan penelitian menunjukkan bahwa Inflasi (X1) secara parsial berpengaruh signifikan terhadap Suku Bunga Bulanan Bank Indonesia (Y) sebelum covid-19. Hal ini dibukitkan dengan nilai $\mathrm{t}$ hitung lebih besar dari $\mathrm{t}$ tabel dengan tingakt signifikansi lebih kecil 0,05.

Hasil penelitian ini menunjukkan bahwa Inflasi dan PDB memiliki pengaruh negatip terhadap suku bunga riil, artinya setiap kenaikan nominal pada vriabel bebas akan menyebabkan tingkat suku bunga riil turun. Persamaan penelitian terdahulu dengan penelitian ini yaitu meneliti variable inflasi terhadap suku bunga bank yang berlaku di Indonesia, sedangkan perbedaannya terletak pada variabel bebasnya, dalam penelitian terdahulu menggunakan product domestic bruto, sedangkan dalam penelitian ini menggunakan harga emas, kurs rupiah.

Temuan penelitian menunjukkan bahwa Harga Emas (X2) secara parsial berpengaruh signifikan terhadap Suku Bunga Bulanan Bank Indonesia (Y) sebelum pandemi covid19. Hal ini dibukitkan dengan nilai $t$ hitung Harga Emas (X2) lebih besar dari $t$ tabel dengan tingkat signifikansi 
lebih kecil 0,05. Harga emas cenderung stabil dari waktu ke waktu bahkan cenderung naik sehingga para pihak investor ataupun masyarakat yang kelebihan dana akan menanamkan dananya untuk membeli emas meskipun tingkat keuntungan tidak begitu tinggi namun dari sisi keamanan investasi emas lebih baik dibandingkan dengan investasi saham, valuta asing ataupun investasi suatu proyek. Hal ini akan menjadi pertimbangan Bank Indonesia dalam mengatur kebijakan moneternya dalam mengatur jumlah uang yang beredar yang berkaitan dengan tingkat suku bunga yang berlaku di bank umum. Semakin tinggi investor yang berinvestasi di sector emas maka jumlah uang yang akan beredar akan semakin berkurang sehingga tingkat suku bunga bank umum yang penentuannya berdasarkan suku bunga Bank Indonesia, maka Suku Bunga Bulanan Bank Indonesia akan dilakukan penyesuaian perubahan meningkat atau menurun.

Teknik analisis data dalam penelitian ini menggunakan analisis data time series dengan model OLS (Ordinary Least Square). Hasil penelitian menunjukkan bahwa: (1) Variabel inflasi berpengaruh positif dan signifikan terhadap harga emas sebesar 3,68\%. (2) Variabel nilai tukar Rupiah terhadap US\$ berpengaruh positif dan signifikan terhadap harga emas sebesar $0,87 \%$. (3) Variabel BI rate berpengaruh negatif dan signifikan terhadap harga emas sebesar $21,8 \%$. (4) Variabel inflasi, kurs dollar dan BI rate secara simultan berpengaruh terhadap harga emas.

Temuan penelitian menunjukkan bahwa Kurs Rupiah (X3) secara parsial berpengaruh signifikan terhadap Suku Bunga Bulanan Bank Indonesia (Y) sebelum pandemi covid-19. Hal ini dibukitkan dengan nilai t hitung Kurs Rupiah (X3) lebih besar dari t tabel dengan tingkat signifikansi lebih kecil 0,05 . Hasil penelitian ini sesuai dengan kebijakan dari Bank Indonesia dalam kapasitasnya sebagai bank sentral Bank Indonesia mempunyai tujuan yaitu mencapai dan memelihara kestabilan nilai rupiah. Temuan penelitian menunjukkan bahwa Inflasi (X) secara parsial berpengaruh dominan terhadap Suku Bunga Bulanan Bank Indonesia (Y) sebelum pandemi covid-19. Hal ini dibuktikan dengan nilai Beta Inflasi (X1) lebih besar dibandingkan dengan nilai beta variabel lainnya.

\section{Analisis Hasil Penelitian Saat Pandemi Covid-19}

\section{Analisis Uji Asumsi Klasik}

\section{Uji Multikolinieritas}

Tabel 5.10

Hasil Uji Multikolinieritas

\begin{tabular}{|l|c|c|c|}
\hline \multicolumn{1}{|c|}{ Variabel } & Tolerance & VIF & Kesimpulan \\
\hline Inflasi (X1) & 0.886 & 1,128 & Nonmultikolinieritas \\
\hline $\begin{array}{l}\text { Harga Emas } \\
\text { (X2) }\end{array}$ & 0.887 & 1,127 & Nonmultikolinieritas \\
\hline $\begin{array}{l}\text { Kurs Rupiah } \\
\text { (X3) }\end{array}$ & 0.897 & 1,115 & Nonmultikolinieritas \\
\hline
\end{tabular}

Sumber : Data diolah

Berdasarkan Tabel 5.10 menunjukkan bahwa hasil perhitungan nilai tolerance lebih dari 0,10 atau $10 \%$ dan nilai variance inflation factor (VIF) kurang dari 10. Jadi dapat disimpulkan bahwa model regresi yang digunakan dalam penelitian ini tidak terjadi gejala multikolonieritas antar variabel bebasnya.

\section{Uji Heteroskedastisitas}




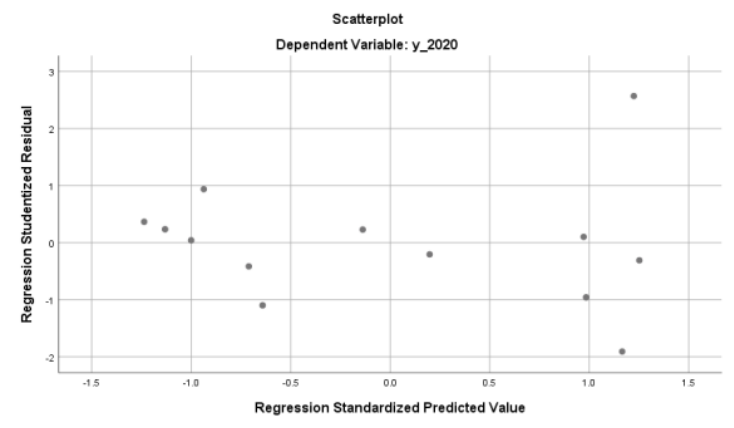

Gambar 5.4 Diagram Scatterplot

Sumber : Data diolah

Berdasarkan grafik scatterplots di atas ini terlihat titik-titik menyebar secara acak serta tersebar baik di atas maupun di bawah angka 0 pada sumbu Y. Hal ini dapat disimpulkan bahwa tidak terjadi gejala heteroskedastisitas pada model regresi, sehingga model regresi layak dipakai untuk memprediksi Suku Bunga Bulanan Bank Indonesia.saat pandemi covid-19

\section{Uji Normalitas}

Uji normalitas ini bertujuan untuk menguji apakah dalam model regresi, variabel pengganggu atau residual memiliki distribusi normal. Asumsi yang harus dipenuhi dalam model regresi adalah yang berdistribusi normal atau mendekati normal. Uji Normalitas ditampilkan pada gambar berikut:

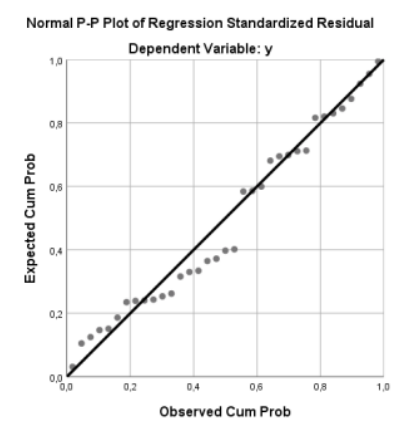

Gambar 5.5 Diagram Normaitas

Sumber : Data Diolah

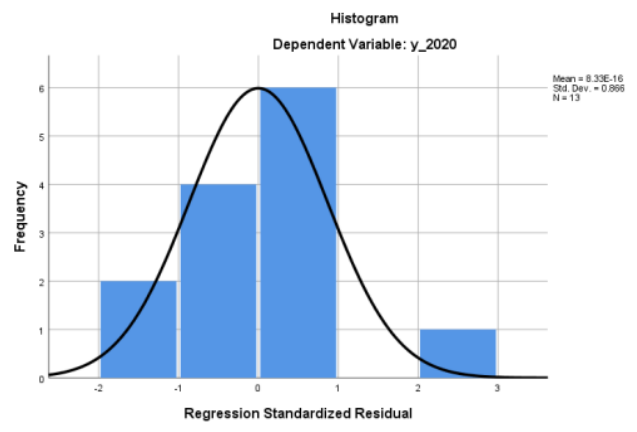

Gambar 5.6 Histogram Normalitas Sumber : Data diolah

Berdasarkan tampilan grafik histogram maupun grafik normal plot dapat disimpulkan bahwa grafik histogram memberikan pola distribusi yang mendekati normal. Sedangkan pada grafik normal plot terlihat titiktitik menyebar disekitar garis diagonal, serta penyebarannya mengikuti arah garis diagonal. Kedua grafik ini menunjukkan bahwa model regresi layak dipakai karena memenuhi asumsi normalitas.

\section{Uji Autokorelasi}

Tabel 5.11

Nilai Durbin

Watson

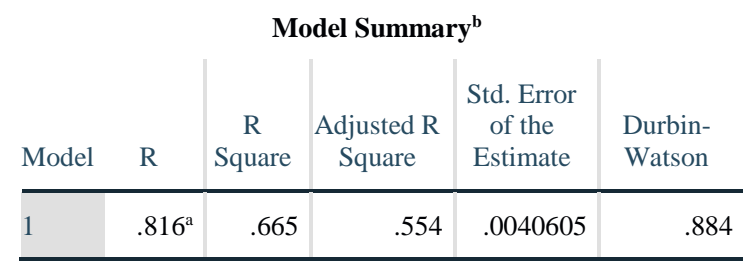

a. Predictors: (Constant), x3_2020, x2_2020, x1_2020

b. Dependent Variable: y_2020

Uji autokorelasi merupakan uji untuk mendeteksi terdapat atau tidaknya 
autokorelasi pada penelitian ini. Deteksi terjadi autokorelasi apabila data penelitian dalam bentuk time series, maka gejala autokorelasi dapat dideteksi dengan indikasi nilai koefisien Durbin Watson sebesar diantara -2 dan +2 . Dalam tabel tersebut diatas nilai Durbin Watson sebesar 0,884 menunjukkan masih lebih besar dari -2 dan masih lebih kecil dari +2 , berarti dalam penelitian ini tidak terjadi autokorelasi dan penelitian ini layak untuk dilakukan.

\section{Hasil Uji Regresi Linier Berganda Saat Pandemi Covid-19}

Tabel 5.12

Koefisien Regresi Linier Berganda

\begin{tabular}{|c|c|c|c|c|c|c|}
\hline & & & oefficier & nts $^{a}$ & & \\
\hline & & $\begin{array}{r}\text { Unstand } \\
\text { Coeffi }\end{array}$ & $\begin{array}{l}\text { ardized } \\
\text { ients }\end{array}$ & $\begin{array}{l}\text { Standardized } \\
\text { Coefficients }\end{array}$ & & \\
\hline & & B & $\begin{array}{l}\text { Std. } \\
\text { Error }\end{array}$ & Beta & $\mathrm{t}$ & Sig. \\
\hline 1 & (Constant) & .028 & .004 & & 6.905 & .000 \\
\hline & x1_2020 & .784 & .193 & .830 & 4.051 & .003 \\
\hline & x2_2020 & .001 & .030 & .005 & .025 & .981 \\
\hline & x3_2020 & .014 & .023 &, 121 & 2.592 & .008 \\
\hline
\end{tabular}

Berdasarkan pada Tabel 5.12 didapatkan persamaan regresi sebagai berikut:

$\mathrm{Y}=0,028+0,784 \mathrm{X} 1+0,001 \mathrm{X} 2-+0,014$ $\mathrm{X} 3+\mathrm{e}$

Dari persamaan di atas dapat diinterpretasikan sebagai berikut:

1. Nilai konstanta (a) bernilai sebesar 0,028 . Nilai tersebut menyatakan bahwa

variabel independen (Inflasi, Harga

Emas dan Kurs Rupiah) jika

dianggap konstan maka Suku Bunga Bulanan Bank Indonesia saat pandemi Covid-19 adalah sebesar 0,028

2. Suku Bunga Bulanan Bank (Y) saat pandemi Covid-19 akan meningkat apabila ada penambahan satu satuan Inflasi (X1). Artinya apabila terjadi peningkatan inflasi maka Suku Bunga Bulanan Bank Indonesia saat Covid-19 akan meningkat sebesar 0,784 satuan dengan asumsi variabel yang lainnya dianggap konstan.

3. Suku Bunga Bulanan Bank (Y) saat pandemi Covid-19 akan meningkat untuk setiap tambahan Harga emas (X2). Artinya apabila harga emas mengalami peningkatan atau penurunan, maka Suku Bunga Bulanan Bank Indonesia (Y) saat pandemi Covid-19 akan meningkat atau menurun sebesar 0,001 satuan dengan asumsi variabel yang lainnya dianggap konstan.

4. Suku Bunga Bulanan Bank Indonesia (Y) saat pandemi Covid19 akan meningkat untuk setiap tambahan Kurs Rupiah (X3). Artinya apabila Kurs Rupiah mengalami peningkatan, maka Suku Bunga Bulanan Bank Indonesia (Y) sebelum Covid-19 akan meningkat atau menurun sebesar 0,014 satuan dengan asumsi variabel yang lainnya dianggap konstan.

Berdasarkan interpretasi di atas, dapat diketahui besarnya kontribusi variabel bebas terhadap variabel terikat, antara lain Inflasi sebesar 0,028. Harga Emas sebesar 0,001 dan Kurs Rupiah sebesar 0,014. Sehingga dapat disimpulkan bahwa Inflasi, Harga Emas dan Kurs Rupiah berpengaruh positif terhadap Suku Bunga Bulanan Bank Indonesia. Dengan kata lain, apabila terjadi perubahan atas variabel Inflasi, Harga Emas dan Kurs Rupiah meningkat, maka akan diikuti peningkatan Suku 
Bulanan Bunga Bulanan Bank Indonesia saat pandemi covid-19.

\section{Koefisen Determinasi}

Uji ini bertujuan untuk menentukan proporsi atau presentase total variasi dalam variabel terikat yang dapat dijelaskan variabel bebas secara bersama-sama.

Tabel 5.13

\begin{tabular}{|c|c|c|c|c|c|}
\hline \multirow[b]{2}{*}{ Model } & \multicolumn{4}{|c|}{$\begin{array}{c}\text { Koefisien Determin } \\
\text { Model Summary }^{\mathbf{b}}\end{array}$} & \multirow[b]{2}{*}{$\begin{array}{l}\text { Durbin- } \\
\text { Watson }\end{array}$} \\
\hline & $\mathrm{R}$ & $\begin{array}{c}\mathrm{R} \\
\text { Square }\end{array}$ & $\begin{array}{l}\text { Adjusted R } \\
\text { Square }\end{array}$ & $\begin{array}{l}\text { Std. Error } \\
\text { of the } \\
\text { Estimate }\end{array}$ & \\
\hline 1 & $.816^{\mathrm{a}}$ & .665 & .554 & .0040605 & .884 \\
\hline
\end{tabular}

Ho ditolak jika $\mathrm{F}$ hitung $>\mathrm{F}$ tabel dan $\mathrm{Ho}$ diterima jika $\mathrm{F}$ hitung $<\mathrm{F}$ tabel. Hasil uji $F$ dapat dilihat pada tabel 5.14 berikut :

Tabel 5.14

Koefisien Uji F (Uji Simultan)

\begin{tabular}{|c|c|c|c|c|c|c|}
\hline \multicolumn{7}{|c|}{ ANOVA $^{\mathrm{a}}$} \\
\hline \multicolumn{2}{|c|}{ Model } & $\begin{array}{l}\text { Sum of } \\
\text { Squares }\end{array}$ & $\mathrm{df}$ & $\begin{array}{l}\text { Mean } \\
\text { Square }\end{array}$ & $\mathrm{F}$ & Sig. \\
\hline \multirow[t]{3}{*}{1} & Regression & .000 & 3 & .000 & 5.962 & $.016^{\mathrm{b}}$ \\
\hline & Residual & .000 & 9 & .000 & & \\
\hline & Total & .000 & 12 & & & \\
\hline
\end{tabular}

Berdasarkan Tabel 5.14 nilai $\mathrm{F}$ a. Predictors: (Constant), x3_2020, x2_2020, x1_2020hitung sebesar 5,962. sedangkan F tabel

b. Dependent Variable: y_2020

Dari analisis pada Tabel 5.13 diperoleh hasil Adjusted $R$ Square sebesar 0,554 artinya bahwa 55,40\% variabel Suku Bunga Bulanan (Y) Bank Indonesia saat pandemi covi-19 dapat dijelaskan oleh variabel bebasnya, yaitu Inflasi (X1), Harga Emas (X2) dan Kurs Rupiah (X3) sebesar $55,40 \%$, sedangkan sisanya $44,60 \%$ variabel Suku Bunga Bulanan Bank Indonesia (Y) saat covid-19 dijelaskan oleh variabel-variabel lain yang tidak diteliti dalam penelitian ini.

\section{Hasil Uji Hipotesis Saat Pandemi Covid- 19}

\section{Hipotesis 1 (F test / Simultan)}

Pengujian $\mathrm{F}$ atau pengujian model simultan digunakan untuk mengetahui apakah hasil dari analisis regresi linier berganda secara simultan berpengaruh signifikan atau tidak, dengan kata lain model yang diduga tepat/sesuai atau tidak. Jika hasilnya signfikan, maka Ho ditolak dan Ha diterima. Sedangkan jika hasilnya tidak signifikan, maka Ho diterima dan Ha ditolak. Hal ini dapat juga diformulasikan sebagai berikut : $(\alpha=0.05 . \mathrm{df}=\mathrm{n}-\mathrm{k}-1=12-3-1=8)$ adalah sebesar 4,070 Karena F hitung > F tabel yaitu 5,962 > 4,070 atau nilai sig $F$ $(0,016)<\alpha=0.05$ maka model analisis regresi adalah signifikan. Hal ini berarti Ho ditolak dan Ha diterima, sehingga dapat disimpulkan bahwa variabel bebas Inflasi (X1), Harga Emas (X2) dan Kurs Rupiah (X3) secara simultan berpengaruh signifikan terhadap Suku Bunga Bulanan Bank Indonesia (Y) saat pandemi covid-19.

2. Hipotesis 2 ( $\mathrm{t}$ test / Parsial)

Uji $t$ test digunakan untuk mengetahui apakah masing-masing variabel bebas secara parsial mempunyai pengaruh yang signifikan terhadap variabel terikat. Dapat juga dikatakan jika $\mathrm{t}$ hitung $>\mathrm{t}$ tabel atau - $\mathrm{t}$ hitung < - t tabel maka hasilnya signifikan dan berarti $\mathrm{HO}$ ditolak dan $\mathrm{Ha}$ diterima. Sedangkan jika $t$ hitung $<\mathrm{t}$ tabel atau -t hitung > - t tabel maka hasilnya tidak signifikan dan berarti Ho diteima dan Ha ditolak. Berdasarkan Tabel 5.7 diperoleh rangkuman hasil koefisien regresi linier berganda sebagai berikut : 
Tabel 5.15

Hasil uji t (Uji Parsial)

t hitung $>\mathrm{t}$ tabel yaitu $0,025<1,860$ atau nilai sig $\mathrm{t}(0,981)>\alpha=0.05$ maka Harga Emas (X2) tidak berpengaruh terhadap Suku Bunga Bulanan Bank Indonesia (Y) saat pandemi covid-19. Hal ini berarti Ho diterima dan $\mathrm{Ha}$ ditolak, sehingga dapat disimpulkan bahwa Suku

StanBunga Bulanan Bank Indonesia (Y) saat Coefficiratemic covid-19 tidak dipengaruhi Unstandardized Coefficients

\begin{tabular}{lll|l|} 
Model & \multicolumn{2}{|c|}{ B } & Std. Error \\
\hline 1 & (Constant) & .028 & .004 \\
\hline x1_2020 & .784 & .193 & \\
\hline x2_2020 & .001 & .030 & \\
\hline x3_2020 & .014 & .023 & 5 \\
\hline
\end{tabular}
Blęh Harga Emas atau degngan naik dan turunnya harga emas dengan kondisi yang berubah ${ }^{6.985}$ seca konfisten maka Suku .83unga Bulaknan Band In $_{3}$ Indonesia (Y) saat pandemi covid-19 tidak mengalămi perubåhan. .981

5 Hasil,121test antâa Kurs Respiah (X3) dengan Suku Bunga Bulanan Bank Indonesia (Y) sebelum covid-19 menunjukkan $\mathrm{t}$ hitung $=2,592$ Sedangkan $\mathrm{t}$ tabel $(\alpha=0.05 ; \mathrm{df}=\mathrm{n}-\mathrm{k}-1=$

Berdasarkan tabel 5.15 di atas dapat dijelaskan sebagai berikut:

3 Hasil t test antara Inflasi (X1) dengan Suku Bunga Bulanan Bank Indonesia (Y) saat pandemi covid-19 menunjukkan $\mathrm{t}$ hitung $=4,051$, sedangkan $\mathrm{t}$ tabel $(\alpha=$ $0.05 ; \mathrm{df}=\mathrm{n}-\mathrm{k}-1=12-3-1=8)$ adalah sebesar 1,860 . Karena $t$ hitung $>\mathrm{t}$ tabel yaitu $4,051>$ atau nilai sig $\mathrm{t}(0,003)<\alpha$ $=0.05$ maka pengaruh Inflasi (X1) terhadap Suku Bunga Bulanan Bank Indonesia (Y) saat pandemi covid-19 adalah signifikan. Hal ini berarti Ho ditolak dan Ha diterima, sehingga dapat disimpulkan bahwa Suku Bunga Bulanan Bank Indonesia (Y) saat pandemi covid-19 dapat dipengaruhi secara signifikan oleh Inflasi atau dengan kata lain bahwa perubahan tingkat Inflasi maka Suku Bunga Bulanan Bank Indonesi (Y) saat pandemi covid-19 akan mengalami perubahan peningkatan secara signfikan.

4 Hasil t test antara Harga Emas (X2) dengan Suku Bunga Bulanan Bank Indonesia (Y) saat pandemi covid-19 menunjukkan $\mathrm{t}$ hitung $=0,025$ sedangkan $\mathrm{t}$ tabel $(\alpha=0.05 ; \mathrm{df}=\mathrm{n}-\mathrm{k}-1=$ $12-3-1=8$ ) adalah sebesar 1,860 Karena 12-3-1 =8) adalah sebesar 1,860. Karena t hitung $>\mathrm{t}$ tabel yaitu 2,592 $>1,860$ atau nilai sig $\mathrm{t}(0,008)<\alpha=0.05$ maka pengaruh Kurs Rupiah (X3) terhadap Suku Bunga Bulanan Bank Indonesia (Y) saat pandemi covid-19 adalah signifikan. Hal ini berarti Ho ditolak dan Ha diterima, sehingga dapat disimpulkan bahwa Suku Bunga Bulanan Bank Indonesia (Y) saat pandemi covid-19 dapat dipengaruhi secara signifikan oleh Kurs Rupiah (X3) atau dengan semakin melemah Kurs Rupiah maka Suku Bunga Bulanan Bank Indonesia (Y) sebelum covid-19 akan mengalami peningkatan secara signifikan.

Berdasarkan hasil temuan penelitian tersebut dapat disimpulkan bahwa variabel bebas mempunyai pengaruh signifikan terhadap Suku Bunga Bulanan Bank Indonesia (Y) saat pandemi covid-19 secara simultan dan parsial, kecuali Harga emas (X2) tidak berpengaruh terhadap Suku Bunga Bulanan Bank Indonesia saat pandemi covid-19.

Hipotesis 3 (Uji Dominan)

Diantara ketiga variabel bebasnya, bahwa variabel bebas yang 
berpengaruh dominan terhadap Suku Bunga Bulanan Bank Indonesia (Y) saat pandemi covid-19 adalah Inflasi karena memiliki nilai koefisien beta 0,830 paling besar dibandingkan dengan variabel yang lain.

Hal ini berarti Ho ditolak dan Ha diterima, sehingga dapat disimpulkan bahwa Inflasi merupakan variabel dominan yang mempengaruhi Suku Bunga Bulanan Bank Indonesia (Y) saat pandemi covid-19

\section{Pembahasan Saat Pandemi Covid-19}

1. Variabel Inflasi (X1), variabel Harga Emas (X2), dan variabel Kurs Rupiah (X3) secara simultan berpengruh signifikan terhadap Suku Bunga Bulanan Bank Indonesia (Y) saat pandemi covid-19

Hasil temuan penelitian membuktikan bahwa secara simultan terdapat pengaruh yang signifikan dari variabel bebas yaitu variabel Inflasi, Harga Emas, dan Kurs Rupaih terhadap Suku Bunga Bulanan Bank Indonesia (Y) saat pandemi covid-19, hal tersebut dibuktikan dengan nilai $\mathrm{F}$ hitung $>$ dari F tabel. Apabila ketiga variabel bebas tersebut mengalami perubahan maka Suku Bunga Bulanan Bank Indonesia (Y) saat pandemi covid-19 ikut meningkat dan begitu pula sebaliknya apabila dalam implementasinya semakin tidak konsisten dan semakin melemah maka Suku Bunga Bulanan Bank Indonesia (Y) saat pandemi covid-19 akan juga semakin meningkat.

2. Inflasi (X1) dan Kurs Rupiah (X3) secara parsial berpengruh signifikan terhadap Suku Bunga Bulanan Bank Indonesia (Y) saat pandemi covid-19,

Temuan penelitian menunjukkan bahwa Inflasi (X1) secara parsial berpengaruh signifikan terhadap Suku Bunga Bulanan Bank Indonesia (Y) saat pandemi covid-19. Hal ini dibukitkan dengan nilai t hitung lebih besar dari $t$ tabel dengan tingkat signifikansi lebih kecil 0,05. Inflasi suatu kondisi yang tidak dapat dihindari oleh siapapun karena inflasi adalah suatu kejadian yang menunjukan kenaikan tingkat harga secara umum dan berlangsung secara terus menerus yang terjadi pada transaksi pasar, karena perilaku dari para pembeli dan penjual maka inflasi tidak dihindari tetapi dapat dikendalikan

Hasil penelitian ini menunjukkan bahwa Inflasi dan PDB memiliki pengaruh negatif terhadap suku bunga riil, artinya setiap kenaikan nominal pada vriabel bebas akan menyebabkan tingkat suku bunga riil turun. Persamaan penelitian terdahulu dengan penelitian ini yaitu meneliti variable inflasi terhadap suku bunga bank yang berlaku di Indonesia, sedangkan perbedaannya terletak pada variabel bebasnya, dalam penelitian terdahulu menggunakan product domestic bruto, sedangkan dalam penelitian ini menggunakan harga emas, kurs rupiah.

3. Temuan penelitian menunjukkan bahwa Harga Emas (X2) secara parsial tidak berpengaruh terhadap Suku Bunga Bulanan Bank Indonesia (Y) saat pandemi pandemi covid-19.

Hal ini dibukitkan dengan nilai t hitung Harga Emas (X2) lebih kecil dari t tabel dengan tingkat signifikansi lebih besar dari 0,05. Pada saat kondisi pandemi covid-19 para investor cenderung bertahan dalam melakukan investasi pada emas mengingat pada pandemic covid-19 tidak dapat diprediksi kapan berakhirnya maka ada kecenderungan menahan diri menunggu keadaan pandemic setelah berakhir.

Temuan penelitian menunjukkan bahwa Kurs Rupiah (X3) secara parsial berpengaruh signifikan terhadap Suku Bunga 
Bulanan Bank Indonesia (Y) saat pandemi covid-19. Hal ini dibukitkan dengan nilai t hitung Kurs Rupiah (X3) lebih besar dari t tabel dengan tingkat signifikansi lebih kecil 0,05.

4. Temuan penelitian menunjukkan bahwa Inflasi (X) secara parsial berpengaruh dominan terhadap Suku Bunga Bulanan Bank Indonesia (Y) saat pandemi covid-19.

Hal ini dibuktikan dengan nilai Beta Inflasi (X1) lebih besar dibandingkan dengan nilai beta variabel lainnya. Laju inflasi tersebut bukanlah suatu standar yang secara mutlak dapat mengindikasikan parah tidaknya dampak inflasi bagi perekonomian di suatu wilayah tertentu, sebab hal itu sangat bergantung pada berapa bagian dan golongan masyarakat manakah yang terkena imbas ( yang menderita ) dari inflasi yang sedang terjadi.

\section{Kesimpulan}

1. Inflasi, Harga emas dan Kurs rupiah secara simultan berpengaruh signifikan terhadap Suku bunga bulanan Bank Indonesia sebelum dan saat pandemi Covid-19.

2. Inflasi, Harga emas dan Kurs rupiah secara parsial berpengaruh signifikan terhadap Suku bunga bulanan Bank Indonesia sebelum pandemi Covid19. Dan Harga emas secara parsial tidak berpengaruh signifikan terhadap Suku bunga bulanan Bank Indonesia saat pandemi Covid-19.

3. inflasi adalah faktor yang mempunyai pengaruh dominan terhadap Suku bunga bulanan Bank Indonesia sebelum dan saat pandemi Covid-19.

\section{Daftar Pustaka}

Abdurrahman dan Sri Handayani. 2014. Earning Management Dan Relevansi Informasi Akuntansi.
Simposium Nasional Akuntansi 17. Mataram.

Abimanyu, Yoopi. 2004. Memahami Kurs Valuta Asing. FE-UI, Jakarta.

Boediono. 2011. Ekonomi Makro, Seri Sinopsis Pengantar Ilmu Ekonomi. Yogyakarta: BPFE

Brigham, Eugene F, dan Joel F Houston. 2010. Dasar-dasar Manajemen.Keuangan.

Penerjemah: Ali Akbar Yulianto. Edisi 10. Buku 1.

Djohanputro, Bramantyo. 2008. Manajemen Risiko Korporat. Jakarta: Penerbit PPM

Dornbusch et.al. 2008. Makroekonomi Edisi Bahasa Indonesia. PT.Media Global Edukasi. Jakarta.

Ekananda, Mahyus. 2014. Ekonomi Internasional. Jakarta: Erlangga.

Gilarso, T..2007. Pengantar Ilmu Ekonomi Makro. Edisi Pertama. IKAPI. Yogyakarta.

Handayani, Sri. 2014. Dampak Manajemen Laba Terhadap Relevansi Informasi Akuntansi. Jurnal Al Hisbah Vol 2 No.1.

Kasmir. 2008. Bank dan Lembaga Keuangan Lainnya Ed. Revisi. Jakarta: PT Raja Grafindo Persada.

Kusumaningsih, Novia. 2015. Pengaruh Variabel Makro Ekonomi Dan Volume Perdagangan Saham Terhadap Indeks Harga Saham Gabungan (IHSG) Di Bursa Efek Indonesia (BEI) Tahun 2009-2014. Skripsi Fakultas Ekonomi Universitas Negeri Yogyakarta

Latumaerissa, Julius R. 2011. Bank dan Lembaga Keuangan Lain, Jakarta: Salemba Empat. 
Mankiw, N. Gregory. 2007. Makro Ekonomi, Edisi ke-6. Jakarta: Erlangga.

Mishkin, Frederic S.2008. Ekonomi Uang Perbankan dan Pasar Keuangan. Edisi. 8. Salemba Empat: Jakarta.

Murni, Asfia. 2013. Ekonomika Makro. PT Refika Aditama: Bandung.

Nanga, Muana. 2005. Makro Ekonomi Teori, Masalah, dan Kebijakan. Edisi Kedua.
Jakarta. PT.Raja Grafindo Persada. ISBN 979-421-85-3.

Natsir, M. 2014. Ekonomi Moneter dan Perbankan Sentral. Jakarta: Mitra Wacana Media.

Nazir, Mohammad. 2011. Metode Penelitian. Jakarta: Ghalia Indonesia.

Nopirin. 2012. Pengantar Ilmu Ekonomi Mikro Makro. Yogyakarta: BPFE Yogyakarta. 